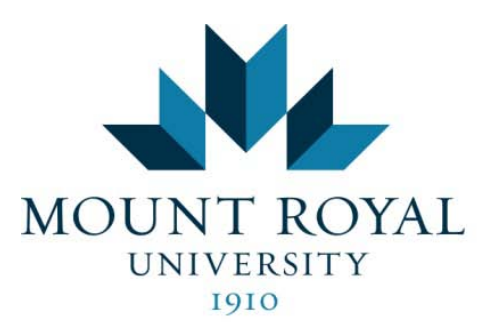

Department of Education and Schooling

Mount Royal Undergraduate Education Review

Volume 1(2)

Fall 2014

\title{
Footprints on the web
}

Joy Barnett, Mount Royal University

Link to Digital Story

\begin{abstract}
This article discusses the topic of digital citizenship and how it relates to current students, preservice teachers, and teachers in the field. It asks the questions; what is digital citizenship? How important is it to teach in elementary? Junior high? High school? What kinds of resources should I, as a pre-service teacher be aware of in my journey to becoming an elementary teacher? I created surveys to address issues and answer some of these research questions. Not only did I send out surveys, I also conducted two interviews to ask extended questions that were raised as I gathered my research. Results showed that current students may or may not realize the importance of digital citizenship, but pre-service and elementary teachers believe it is crucial that this topic be covered in the classroom. This research project is profound for teachers that are developing a teaching philosophy.
\end{abstract}




\section{Introduction}

I have always been an advocate for being the same person everywhere you go! I know it sounds strange, but there is a lot of integrity involved in presenting the same person to others no matter where you are, and what you are doing. Who we are on the internet is no different; in fact, it may be more important to present a positive, safe, and ethical image of yourself online. Many people use the internet as something they can hide behind and say things, or post things that they would not face-to-face. We need to be ensuring that our we are being good citizens in out digital life. But digital citizenship isn’t limited to that. With a new world of technology comes opportunity and challenges. Are children aware of the dangers that online resources introduce? Do they know how to keep their personal information safe? Do they know how to manage themselves online? My research is directed towards pre-service teachers, current students, and elementary school teachers to see how each group views digital citizenship. Different perspectives is interesting when you can look through three different lenses on the same topic.

My specific research questions are; do elementary teachers actually teach digital citizenship? If so, to what extent? What should I, as a pre-service teacher, know about this topic so I can effectively teach it to my future students? These inquiry questions are clear and well stated, and definitely relates to elementary education. The results of this study will inform me on how to address this topic in my classroom, and how to educate my students and encourage them to have digital citizenship.

\section{Background}

As stated in Ribble’s (2012) article, digital citizenship is defined as, “critical thinking and ethical choices about the content and impact on oneself, others, and one's community of what one sees, says, and produces with media, devices, and technologies” (p. 149). In this new world of digital citizenship, unfortunately, students are currently taking the lead. "Though teachers are trying to "catch up" with their students, many were not provided instruction in these skills during their preservice training” (Ribble, 2012, p. 149). This is becoming a problem as teachers integrate technology into the classroom without having sufficient knowledge of how to utilize it effectively, but also how to teach children how to operate themselves appropriately with it. Many times, teachers begin to rely on technology to do part of their job. Ribble (2012) states that "the pedagogy must not be lost... technology can make education more efficient, but it cannot be a 
replacement for good teaching... it [is] a tool for helping to support and extend the learning experience” (p. 141). According to Davison (2014), it’s “best to introduce technology early, teach students how to be good digital citizens, and bring parents along on the journey” (p. 32). Davison introduces an important aspect of this topic. Parents. According to Sabella (2010), "parents are not taking the time and effort to educate themselves... they have made it the responsibility of the schools. But the schools didn't give the kids their cell phones” (as cited in Ribble \& Miller, 2013, p.136). Since students spend their days both at home as well as at school, teachers and parents must work together to ensure that the children are not living two lives. The "two lives approach assumes that students should unplug when they enter school, and then plug back in when they leave for the day” (Ohler, 2011, p. 25). Instead, technology needs to be integrated into the classroom, but should always begin with instructional goals and then move towards technology initiatives (Johnson, 2014, p. 86). Any time there is use of technology in the classroom, it should be a manifestation of the teacher's thoughtful intention to include it.

One idea that was discussed in the articles I used for my research was the notion of having students attain a DDL - digital driver's license. Just like an individual must work to get a motorist license, a course online would be set up with modules to be completed. This course would teach students "how to recognize and react to precarious situations online, such as cyberbullying and copyright infringement” (Swan \& Park, 2012, p. 26). This way, each student will be 'certified' to use the technology in the classroom. However, digital citizenship is not just for the students, it "will be needed for all groups - faculty members, students, and community members” (Ribble, 2012, p. 140). An old Nigerian proverb says, “Ora na azu nwa,” which means “it takes a village to raise a child” (Hollandsworth, Dowdy, \& Donovan, 2011, p. 37). For our students, who is included in that village as it relates to digital citizenship? In the words of Hollandsworth et al. (2011), “will it be parents, teachers, administrators, academics, technology professionals, media specialists, or students? ... It will require all of us” (p. 38).

\section{Research Context}

For my research project, I wanted to reach a diverse population of people. This allows me to look through multiple lenses on the same topic. I chose those that are currently working through the K-12 system, those who are pre-service teachers like myself, and those who are elementary teachers working in the field. Specifically, I selected my research participants to be 
one of my siblings, asking them if his teachers have ever discussed digital citizenship, as well as pre-service teachers to interview and get thoughts on the importance of this topic in their pedagogical viewpoint, and lastly, teachers, asking them if they educate their students on digital citizenship and the extent that they cover the topic in their classrooms. Overall I received 11 responses from the three sample populations that I was interested in surveying.

To be able to clearly collect data from three different lenses, I created three different surveys. In each demographic, I reassured the participants that their information was confidential and anonymous. I explained that their input was valuable and would help me to draw conclusions about digital citizenship. Lastly, I communicated that I appreciated their time and that their response would impact my future practice as an elementary school teacher.

\section{Methods of Investigation}

In my research, I mainly relied on surveys as my main form of investigating. I sent my surveys out to teacher candidates at Mount Royal, elementary school teachers in the field, as well as one response from a student currently going through the K-12 school system. In the surveys, I designed a variety of types of questions so my participants were not limited to long answer or multiple choice. I also referred to a couple interviews to clarify some of the responses I got from the survey. These interviews were with two of my fellow teacher candidates. I asked each of them a question that my data did not outline for me. The first interview posed the question, "At what time in a student's life, younger or older, should educators really focus on this idea of digital citizenship?” I was interested in this response because my data showed that some thought teachers should focus on younger students so they would be prepared for later on. Others thought older because they are more at risk with social media and other online outlets. My second question asked, "How do teachers find a balance with digital technology in the classroom so that it is integrated, but does not replace good teaching methods?” I needed some clarification because responses were strong in the integration of technology, but that it shouldn't be too much. The answers to these questions will be presented in the findings and conclusion.

To analyze my data, I used Google Spreadsheet, and word clouds to capture images as my representation of the responses I received. For the word cloud, I thought it would be interesting to use the words that people used to define digital citizenship. I decided to organize my data mainly in graphs and charts. These provide a succinct way of depicting data in a way 
that is easy to read, and visually appealing. I left some of the responses in text so I can refer to them in my "findings" section.

\section{Findings}

In the following section, I will unpack the results that I received from my participants by using the graphs and pictures that summarize my findings. In this study, I sought to discover what the general thoughts were on the definition of digital citizenship, whether digital citizenship is something that elementary teachers should teach to the various age categories of elementary, junior high, and high school and why? And lastly, I asked what resources should I, as a preservice teacher, know about so I can effectively teach it to my future students?

The results I received from my participants are split into three categories as mentioned previously. I wanted to study a current student, preservice teachers, and elementary teachers in the field to allow for a well rounded view on the topic of digital citizenship. Firstly, we will look at the results I received from my current student.
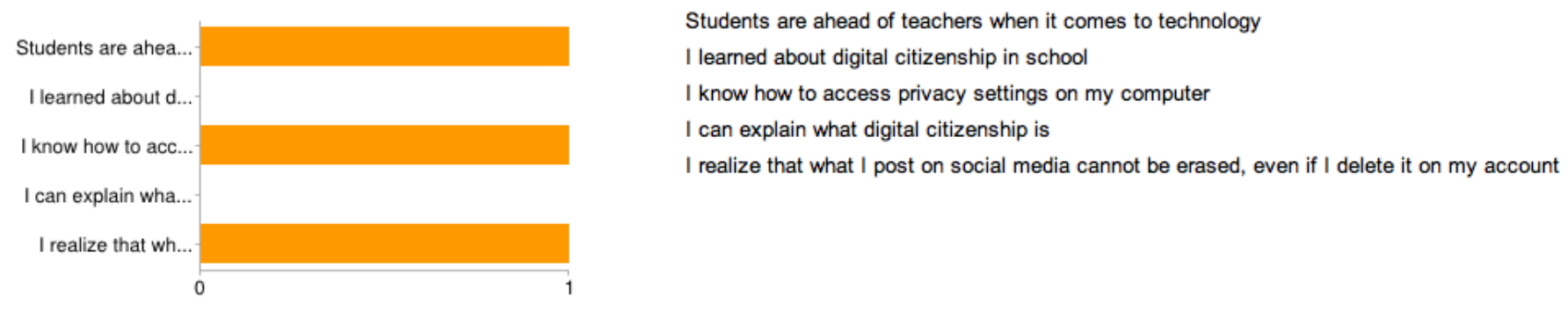

Figure 1. Student perspectives

In Figure 1, the current student agreed with three of the five statements on the survey. It is interesting to note that this person did not learn about digital citizenship in schools, cannot explain what it is, but has an understanding of the consequences of things posted online. More importantly, the individual agrees that students are ahead of teachers with technology, confirming the need for teachers to catch up and provide safe introductions to new forms of digital devices or social media outlets. Below are the rankings the participant gave to each grade level when asked to rank the importance of teaching digital citizenship to a) elementary, b) jr. high, and c) high school. 5 is considered the most important. 


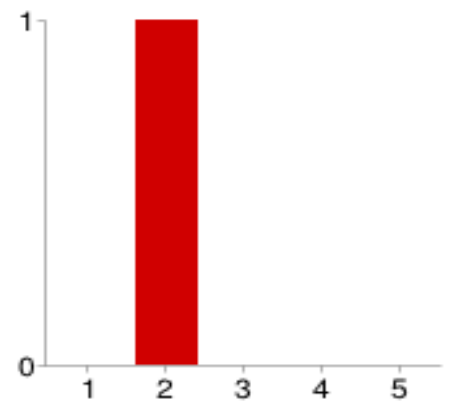

$\begin{array}{rrr}\mathbf{1} & \mathbf{0} & 0 \% \\ \mathbf{2} & \mathbf{1} & 100 \% \\ \mathbf{3} & \mathbf{0} & 0 \% \\ \mathbf{4} & \mathbf{0} & 0 \% \\ \mathbf{5} & \mathbf{0} & 0 \%\end{array}$

Figure 2. Importance of digital citizenship in elementary education - current student perspective

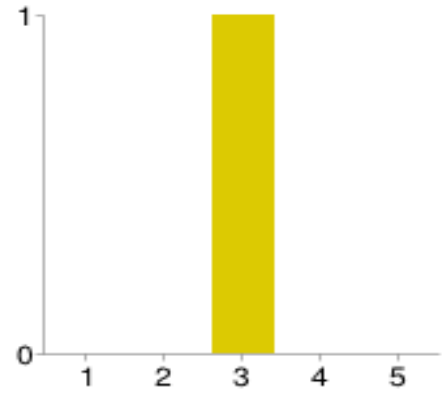

$\begin{array}{rrr}\mathbf{1} & \mathbf{0} & 0 \% \\ \mathbf{2} & \mathbf{0} & 0 \% \\ \mathbf{3} & \mathbf{1} & 100 \% \\ \mathbf{4} & \mathbf{0} & 0 \% \\ \mathbf{5} & \mathbf{0} & 0 \%\end{array}$

Figure 3. Importance of digital citizenship in junior high - current student perspective

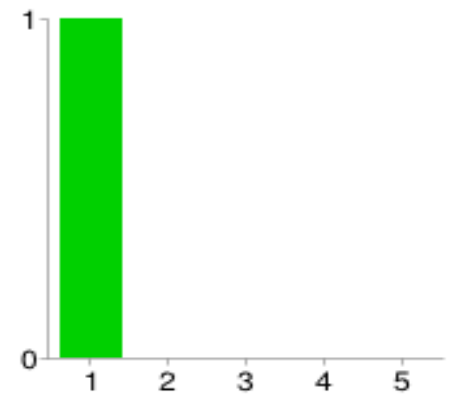

$\begin{array}{llr}\mathbf{1} & \mathbf{1} & 100 \% \\ \mathbf{2} & \mathbf{0} & 0 \% \\ \mathbf{3} & \mathbf{0} & 0 \% \\ \mathbf{4} & \mathbf{0} & 0 \% \\ \mathbf{5} & \mathbf{0} & 0 \%\end{array}$

Figure 4. Importance of digital citizenship in high school - current student perspective

Clearly, the participant did not think that teaching digital citizenship was all that important at any age. However, junior high seemed to be the years that it was more important than the others. The individual's comment to high school being the lowest was that, "high school kids should be responsible for themselves and what they do online.” (Barnett, 2014, p.1). From 
this feedback, it is possible to conclude that students might not realize the importance of teaching digital citizenship. In my survey, when this current student was asked to define digital citizenship, a very poor definition was given. For this reason, I believe it is even more important to teach, accurately, what digital citizenship is and how it is going to be of benefit to the student. This student seems to believe that by teaching digital citizenship a teacher is controlling online activities. My response to that is that teachers are not controlling online activities, they are educating students on the healthy and unhealthy ways to use online outlets. Because I only had one current student response, it is difficult to generalize my findings. In the end, regardless of being educated on the subject, students will always have a choice in what they engage online. A teacher's job is to best equip their students with the knowledge of how to make the best choices and protect activities that go on in their classrooms.

Secondly, the results from pre-service teachers were much different. What is digital citizenship? According to pre-service teachers at MRU, this word cloud depicts their responses. The words that appear larger were used more frequently than the words that are smaller.

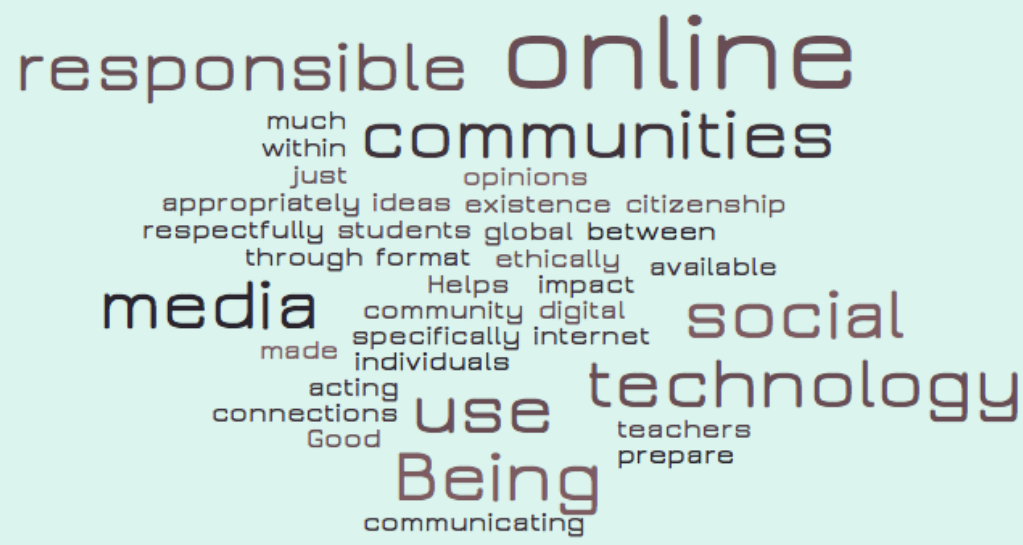

Figure 5. Word cloud definitions from pre-service teachers at Mount Royal University

This word cloud highlights the thoughts from my fellow peers about their ideas on what digital citizenship is. Many used words like, 'responsible,' 'media,' and 'community,' to describe. This definition is fairly accurate for participants who have not studied digital citizenship. Simply, digital citizenship is the idea of using technology in an appropriate manner. 

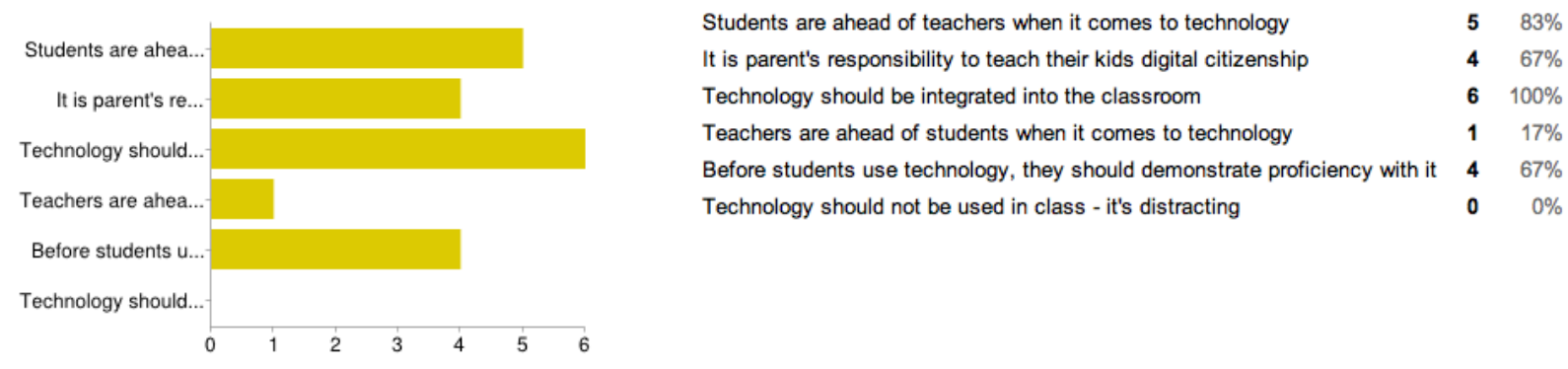

Figure 6. Pre-service teacher perspectives

Above depicts the statistics on the preservice teachers who agree with the statements in the graph. Similar to the response of the current student, five of six participants that students are ahead of teachers when it comes to technology. What I find the most interesting part about these results is that all my participants agreed that technology should be integrated into the classroom no one thought technology shouldn't be used in class - but also that four out of six thought that it is the parents responsibility to teach their children about digital citizenship. It is unclear as to whether these participants think it is solely the parent's responsibility, or if parents and teachers are to work together to teach digital citizenship. From what I gather, I think it is not wise to skip over the topic because it has been assumed that since the parents have bought the children technology, that they will also teach them how to responsibly operate on it. As found in my research, it "will it be parents, teachers, administrators, academics, technology professionals, media specialists, [and] students ... It will require all of us” to teach digital citizenship (Hollandsworth et al., 2011, p. 38). The graphs below depict the rankings pre-service teachers gave to a) elementary b) jr. high and c) high school regarding the importance of teaching digital citizenship. A ranking of ' 1 ' shows that teaching digital citizenship is not important at all, whereas a ‘5' represents a strong importance in teaching children about digital citizenship.
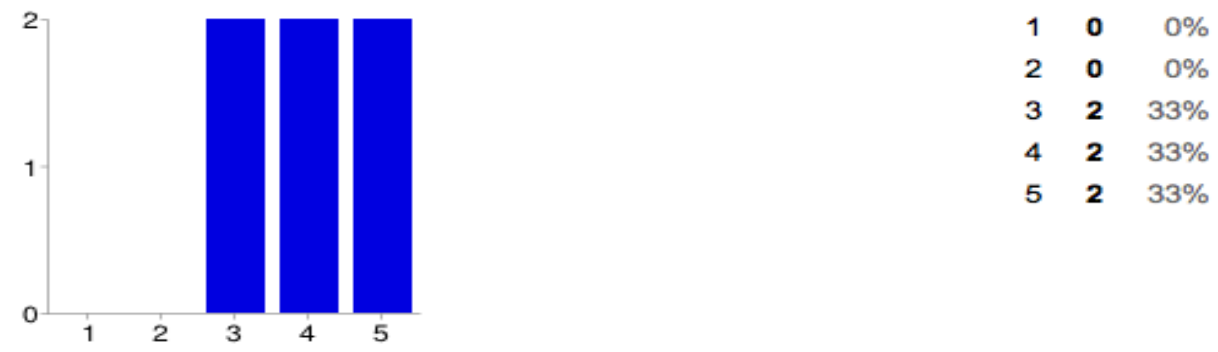

Figure 7. Importance of digital citizenship in elementary - pre-service teacher perspective 


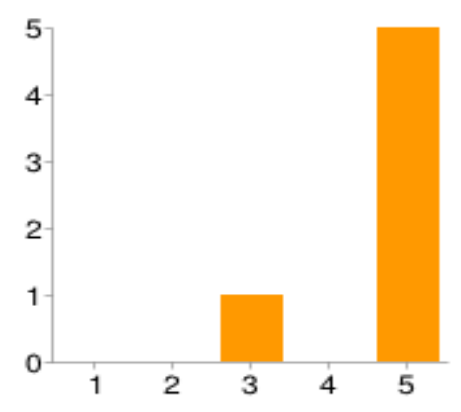

$$
\begin{array}{rrr}
1 & \mathbf{0} & 0 \% \\
2 & \mathbf{0} & 0 \% \\
\mathbf{3} & \mathbf{1} & 17 \% \\
\mathbf{4} & \mathbf{0} & 0 \% \\
\mathbf{5} & \mathbf{5} & 83 \%
\end{array}
$$

Figure 8. Importance of digital citizenship in junior high - pre-service teacher perspective

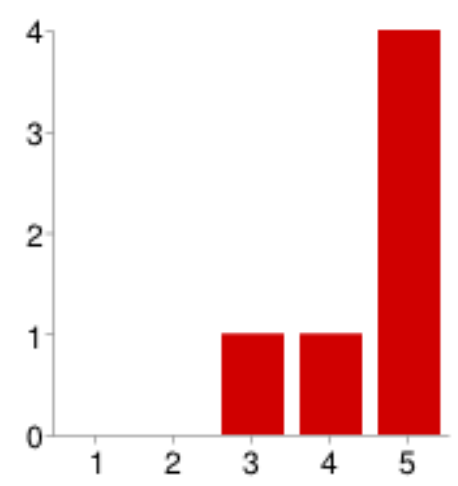

$$
\begin{array}{rrr}
1 & \mathbf{0} & 0 \% \\
2 & \mathbf{0} & 0 \% \\
\mathbf{3} & \mathbf{1} & 17 \% \\
\mathbf{4} & \mathbf{1} & 17 \% \\
\mathbf{5} & \mathbf{4} & 67 \%
\end{array}
$$

Figure 9. Importance of digital citizenship in high school - pre-service teacher perspective

From the responses of pre-service teachers for elementary levels, there is an even split from moderately important (3), important (4), and very important (5). For junior high, there is a clear belief in high importance for teaching digital citizenship, and in high school, we see more of a split, but still a strong value to teach it with only two participants ranking 3, and the other, 4 . Generally, the reasons pre-service teachers were divided so evenly in elementary importance was because some believed that you need to equip children for future years, while others believed that since they are not engaging in high levels of technology, that it is more important for older years. In an interview with one of my peers, the individual spoke about starting early, teaching a positive digital footprint, and that there are many different ways of approaching the same subject of digital citizenship based on what grade level they are (Lohman, 2014). This participant was an advocate for including something about digital citizenship in every grade level. Reasoning for jr. high importance pointed to an increase in overall usage, as well as more dangerous activities more available to students of this age level. For high school, pre-service teachers still rank it important because it's possible not all students have been taught digital citizenship, and 
reminders are always promoting safety in the classroom and online. In high school, students have their own agency. By this time, teachers hope that students are not hearing about digital citizenship for the first time. Through making their own choices about their online footprint and involvement in social media, teachers can continue to discuss elements of digital citizenship that directly influence this age group. In this way, it doesn't become childish or seem like the teacher is controlling online behaviours, but instead fostering safety and healthy online agency.

Lastly, I surveyed four teachers that are actively employed in the K-12 system right now. Their feedback is very enlightening to my research and they have provided me with some resources to look further into in my topic. When asked what digital citizenship is, this word cloud summarizes the teacher's responses.

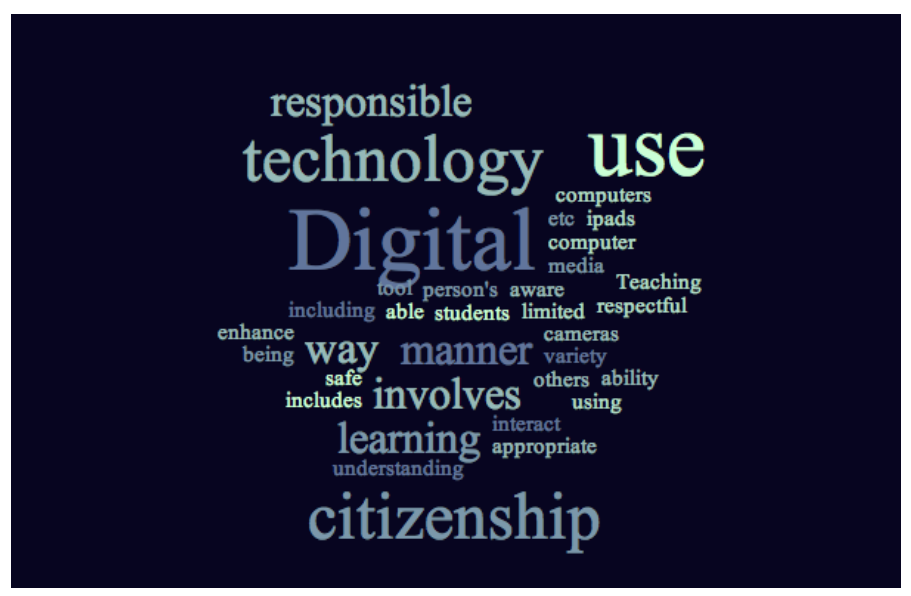

Figure 10. Word cloud definitions from elementary teachers

These words clearly depict a strong knowledge of what digital citizenship is. The words 'manner,' 'responsible,' and 'citizenship' are words that many of the experts on my topic used when discussing digital citizenship. In another part of my survey, I posed statements that the teachers had to decide if they agreed with or not. The following image depicts their response.

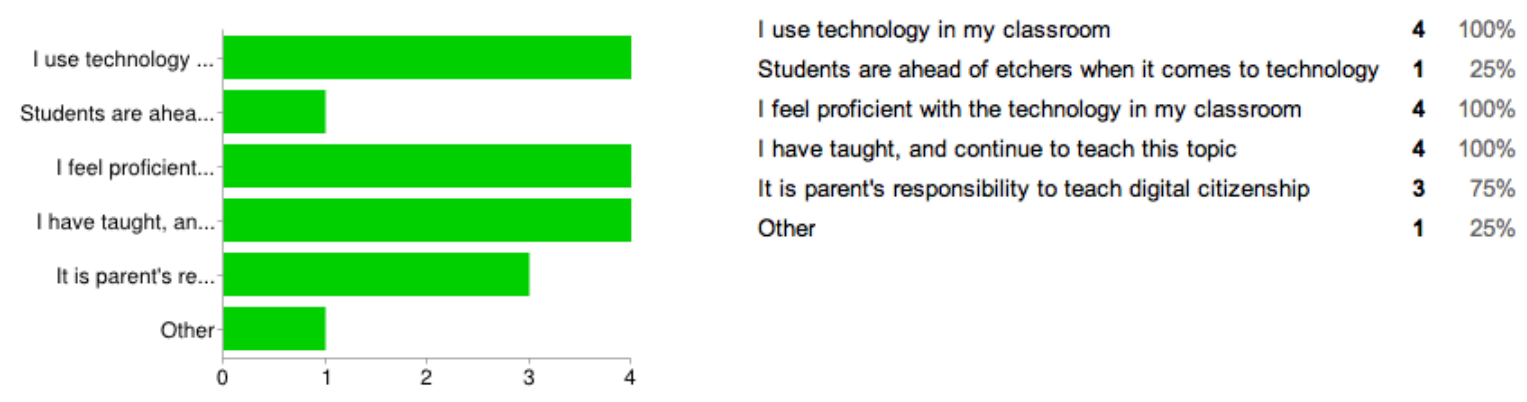

Figure 11. Elementary teacher perspectives 
It is interesting to note that all four participants agreed that they use technology in the classroom, and that they feel proficient with it. In addition to this, all teachers have taught, and continue to teach digital citizenship. It is good to see that the integration of technology in these classrooms is paired with an overall confidence in the teachers around how to operate themselves on it, as well as the continuation of teaching others how to manage themselves with technology. On another note, only one teacher thought that students are leading the way in technology. In my research, most authors stated the worry that teachers were behind in technology, but maybe teachers in the field do not share the same feelings. Three out of four of the participants agreed that parents play a role in the teaching of digital citizenship. Taking into consideration all the statements, it is clear that parents should be taking the initiative alongside the teacher for an effective development of digital citizenship in our youth. When asked to rank the importance of teaching digital citizenship in a) elementary, b) junior high, and c) high school, this is what teachers thought.

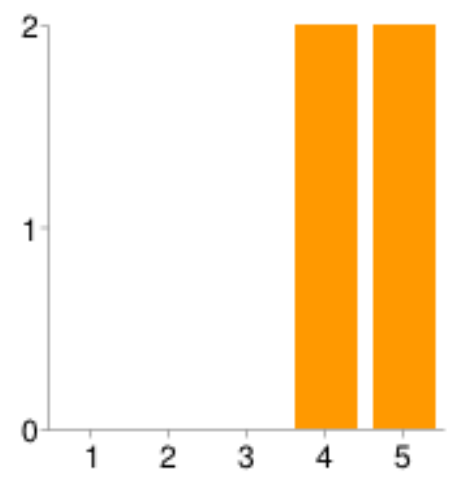

$$
\begin{array}{rrr}
1 & \mathbf{0} & 0 \% \\
2 & \mathbf{0} & 0 \% \\
3 & \mathbf{0} & 0 \% \\
4 & \mathbf{2} & 50 \% \\
\mathbf{5} & \mathbf{2} & 50 \%
\end{array}
$$

Figure 12. Importance of digital citizenship in elementary school - teacher perspective

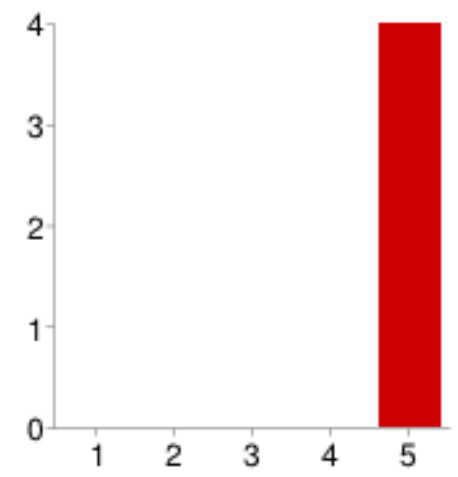

$$
\begin{array}{rrr}
1 & \mathbf{0} & 0 \% \\
2 & \mathbf{0} & 0 \% \\
3 & \mathbf{0} & 0 \% \\
4 & \mathbf{0} & 0 \% \\
\mathbf{5} & \mathbf{4} & 100 \%
\end{array}
$$

Figure 13. Importance of digital citizenship in junior high school - teacher perspective 


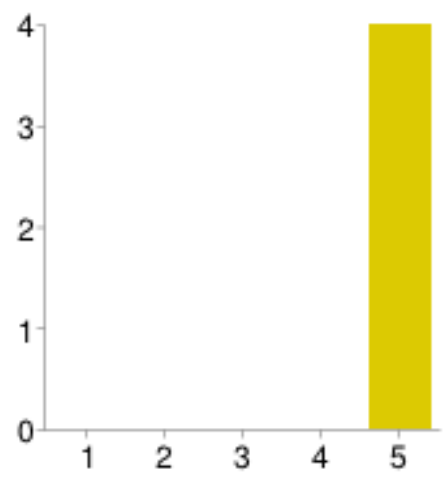

$\begin{array}{rrr}1 & \mathbf{0} & 0 \% \\ 2 & 0 & 0 \% \\ 3 & 0 & 0 \% \\ 4 & 0 & 0 \% \\ \mathbf{5} & \mathbf{4} & 100 \%\end{array}$

Figure 14. Importance of digital citizenship in high school - teacher perspective

Among teachers, this topic is clearly very important to teach. Reasoning for elementary levels among teachers included that there are filter systems for internet usage, making it more difficult for children to find themselves vulnerable to websites, as well as family life and school life contain technology to an increased extent in the 21st century, so beginning in kindergarten is a smart idea. Jr. High was rated '5,' and teachers mentioned the increased amounts of freedom that these students have on the internet, as well as that now they can be the creators of websites and internet accounts. Because of these things, it is imperative they understand the risks and consequences. Lastly, for high school, teachers reasoned that students at this age are nearly independent on technology and can not only create, but also have the capacity to teach others how to use it or misuse it. In high school, users can either be victims or abusers. Like adults, high school students still need to be reminded of appropriate internet and technology use from time to time. For these reasons, elementary teachers ranked a ' 5 ' on the importance of teaching digital citizenship.

At any age, digital citizenship is important for learners to be conducting themselves in a respectable manner. At each age level, students are involved differently with technology; therefore making it even more important that they understand that involvement and the consequences their actions have to themselves and others. The last question of my survey I asked for resources that I could look up that would help me to learn more about my topic. The following is a list of the ones that were offered to me:

- Teacher goes viral with lesson about dangers of posting online - CBC News

- International Society for Technology in Education (ISTE) Student Standards

- $\quad$ Calgary Board of Education Digital Citizenship Resources 
- Individual School Plans for digital citizenship

\section{Conclusions and Recommendations}

After completing this study, there were some things discovered that will profoundly influence my teaching pedagogy and approach when I become an elementary teacher. Before I conducted the surveys, I knew digital citizenship was important - just like being a good citizen in 'real world' is important; however, the results showed me just how crucial it is to be teaching digital citizenship at every age! In elementary, digital citizenship looks like an introduction to technology, while parents and teachers still remain quite protective over the access and extent that children are exposed to it. As these children move into jr. high, digital citizenship looks more like educating students on the responsibility that they have to manage themselves online in a respectful, appropriate way. In high school, digital citizenship could be reminders of online etiquette and safety precautions. Most importantly though, my research has revealed that elementary teachers are aware that this topic should be taught as we see an increase in the use of technology in the classroom. This study showed me that elementary teachers are aware what digital citizenship is, and that they do actively teach it. These teachers teach it to the extent that they need to in their classrooms. If all they use are iPads, then that's the level of education the children receive. Any technology that comes into the classroom determines the extent and level of digital citizenship that will be taught.

Because of these findings, my practice as an elementary teacher will involve the teaching of digital citizenship. It has also been made clear that parents and other authority figures are an important part of the teaching process for this topic. In one form or another, teachers need to communicate with parents about the importance of this issue so they can work together to create safe, appropriate atmospheres around technology both inside and outside the classroom.

My research has answered many questions, but also raised some questions as well. Everyone in my study agreed that it was important to integrate technology into the classroom. However, they also agreed that technology should never take the place of good teaching and learning methods completely. The question becomes, where does a teacher draw the line between too much technology and not enough? How do teachers balance this idea of technology assisting learning and the good old fashioned method of the teacher being the source of knowledge and 
communication? In addition to this, my study did not consider the 'how' in teaching students digital citizenship. Are there right and wrong ways to teach this? What kind of strategies could a teacher use to more effectively engage students in a discussion about safety online? Lastly, it would be interesting to see how much students might already know about digital citizenship at any given age. If I were to do another study, I would want to find out what elementary, jr. high, and high school students already know about this topic, and whether or not they think it is important to learn about. Ultimately, digital citizenship is far more important in classrooms that utilize technology than most realize, and it is our job as future teachers and parents to educate our students how to manage themselves on it in a safe, responsible, and appropriate manner.

\section{References}

Davison, S. E. (2013). It’s never too soon to teach digital citizenship. Learning \& Leading With Technology, 41(4), 32-33.

Hollandsworth, R., Dowdy, L., \& Donovan, J. (2011). Digital citizenship in K-12: It takes a village. Techtrends: Linking Research \& Practice To Improve Learning, 55(4), 37-47. doi:10.1007/s11528-011-0510-z

Johnson, D. (2014). Your 1:1 Program: Can you answer these 10 questions?. Educational Leadership, 71(8), 86-87.

Ohler, J. (2011). Digital citizenship means character education for the digital Age. Kappa Delta Pi Record, 48(1), 25-27.

Ribble, M. (2012). Digital citizenship for educational change. Kappa Delta Pi Record, 48(4), 148-151. doi:10.1080/00228958.2012.734015

Ribble, M., \& Miller, T. (2013). Educational leadership in an online world: Connecting students to technology responsibly, safely, and ethically. Journal Of Asynchronous Learning Networks, 17(1), 135-143.

Swan, G., \& Park, M. (2012). Students need a digital driver's license before they start their engines. Learning \& Leading With Technology, 40(4), 26-28. 